Relations industrielles

Industrial Relations

\title{
Réformes de structure et syndicalisme
}

Volume 3, numéro 10, juin 1948

URI : https://id.erudit.org/iderudit/1023639ar

DOI : https://doi.org/10.7202/1023639ar

Aller au sommaire du numéro

Éditeur(s)

Département des relations industrielles de l'Université Laval

ISSN

0034-379X (imprimé)

1703-8138 (numérique)

Découvrir la revue

Citer cet article

(1948). Réformes de structure et syndicalisme. Relations industrielles /

Industrial Relations, 3(10), 155-155. https://doi.org/10.7202/1023639ar

Tous droits réservés (C Département des relations industrielles de l’Université Laval, 1948
Ce document est protégé par la loi sur le droit d'auteur. L’utilisation des services d'Érudit (y compris la reproduction) est assujettie à sa politique d'utilisation que vous pouvez consulter en ligne.

https://apropos.erudit.org/fr/usagers/politique-dutilisation/ 
the apprenticeship training problem in every line of industry. There is ever increasing evidence that top ranking labour leaders are inclining more and more to the view that labour organizations should display greater interest in promoting ways and means of increasing the average efficiency and productivity of labour and it behooves employer organizations everywhere to welcome every sign of this interest. The success which has attended the efforts of the Montreal Building Trades Apprenticeship Commission is a striking example of what can be accomplished through the cooperative action of management and labour, when both have an equal say in things.

It would be impossible to praise too highly the part which organized labour has played in contributing to the success of the building trades apprenticeship programme in Montreal since the inception of the Apprenticeship Commission two and a half years ago. Thanks principally to the help provided by the labour members of the Commission, the percentage of the mechanics' wage rate allowed for apprentices in each year of apprenticeship has been increased substantially; each apprentice is given a practical trade test by labour repersentatives on completing his six months of initial training at the Centre with the knowledge that good marks will win for him some shortening of the period of his apprenticeship; the allowable ratio of apprentices to mechanics has been increased; to mention only a few of the concessions which would never have been obtained without the support of labour.

In spite of some past predictions to the contrary, enrollment for training at the Centre is continuing at a satisfactory rate and there has been no particplar difficulty in filling the gaps left by the veteran trainees who have now almost entirely disappeared from the scene. Vocational guidance activities in the Catholic and Protestant High Schools throughout the City provide a steady stream of youths interested in seeking careers in the building trades. In dealing with these young men, it is the constant effort of the Commission staff to impress upon them that enrollment at the Centre means much more than just an opportunity to learn a trade. Every trainee is encouraged to regard enrollment at the Centre as the first rung in a ladder which can be made to lead to a place at the top of the construction industry, which is to say in Canada's second largest industry.

Up to this time, the expense incurred by the Commission has been defrayed out of grants from the Provincial Government and the Montreal Building Trades Joint Committee respectively and per diem allowances from the Dominion Government to cover the cost incurred in the training of veterans.

The Commission is ever mindful of the extent to which its progress has been made possible through the unfailing interest and influence of the Minister of Labour.

If the reaction of the great majority of all of the employers who are employing the apprentices coming from the Training Centre is any criterion, there is every assurance that the Montreal Building Trades Apprenticeship Commission is well on the way to accomplishing the purpose for which it was created, this being the raising of the standards of efficiency and productivity in all of the building trades, for the lasting benefit of both the employer and the employee.

\section{REFORMES DE STRUCTURE ET SYNDICALISME}

On nous a demandé si les réformes de structure que nous avons envisagées dans de nombreux articles au cours de cette année pouvaient s'accomplir sans les syndicats et si elle ne risquaient pas d'entraîner, peu à peu, mais sûrement, la disparition du syndicalisme. Nous avons l'intention de revenir sur ce sujet. En attendant, voici l'opinion des RR.PP. G. Desbuquois et P. Bigo tel qu'exprimée dans «Les réformes de l'entreprise et la pensée chrt.e...e", Spes, Paris, page 21:

«De même qu'elle ne peut réussir si elle ne s'intègre à une organisation professionnelle cohérente, la réforme de l'entreprise doit s'appuyer sur un syndicalisme fort. Rien ne serait plus néfaste que de vouloir revenir en arrière sur ce point, comme si la participation du personnel à l'entreprise devait remplacer la défense de ses intérêts sur le plan syndical. L'idée communautaire, qui tend à renouer une solidarité naturelle entre la propriété et le travail, ne s'oppose pas à l'idée syndicale qui groupe les hommes «suivant la situation qu'ils ont sur le marché du travsil. Tout au contraire, les deux idées se complètent et s'équilibrent l'une l'autre. On les trouve toutes deux aussi nettement affirmées dans tout l'enseignement de l'Eglise. Lorsque l'idée syndicale s'estompe, la défense des intérêts ouvriers s'affaiblit dangereusement. Si l'idée communautaire est négligée, le conflit entre le capital et le travail s'aggrave. Seuls, des hommes aux convictions syndicales à labri de tout soupcon pourront mener à bien la transformation de l'entreprise sur des bases communautaires, et les organisations syndicales du personnel devront dans tous les cas y jouer un rôle actif. »

\section{NOS COLLABORATEURS}

Bélanger, Charles, B.Sc.Soc., secrétaire du district de Québec de la Commission du salaire minimum et assistant-secrétaire du Département des relations industrielles de l'Université Laval.

Clément, Marcel, licencié ès lettres, diplômé d'études supérieures de philosophie (Sorbonne), licencié en droit. Diplômé d'études supérieures d'économie politique (Faculté de droit de Paris), professeur à la Faculté des sciences sociales de Laval.

Price, J.L.E., M.E.I.C., président de J.L.E. Price \& Co. Ltd., entrepreneur en construction, président du Centre d'apprentissage des métiers du bâtiment de Montréal 